\title{
Influence of anxiety on the heart rate variability of patients in preoperative
}

\section{orthopedic surgery}

\author{
Influência da ansiedade na variabilidade da frequência cardíaca de pacientes em pré-operatório de \\ cirurgia ortopédica
}

Influencia de la ansiedad en la variabilidad de la frecuencia cardíaca de los pacientes en cirugía ortopédica preoperatoria

Received: 06/16/2021 | Reviewed: 06/21/2021 | Accept: 06/22/2021 | Published: 07/09/2021

Francielly V. Correa

ORCID: https://orcid.org/0000-0003-2654-8579 Western Paraná State University, Brazil E-mail: franhuop@gmail.com

Aline M. Diolindo Meneses

ORCID: https://orcid.org/0000-0002-8045-4613 Scientifical and Tecnological Insitute, Brazil University, Brazil E-mail: md.aline@hotmail.com

Sara P. Carvalho

ORCID: https://orcid.org/0000-0001-7421-8289 Western Paraná State University, Brazil

E-mail: sarapriscilacarvalho@hotmail.com

Antônio P. Mendes

ORCID: https://orcid.org/0000-0001-7802-6815 Scientifical and Tecnological Insitute, Brazil University, Brazil

E-mail: paduamendes@gmail.com

Laurita dos Santos

ORCID: https://orcid.org/0000-0002-6363-6837 Scientifical and Tecnological Insitute, Brazil University, Brazil

E-mail: lauritas9@gmail.com

\begin{abstract}
Anxiety is a negative emotional response to situations that threaten the subject. Objective: The present study aims to verify the influence of anxiety on heart rate variability, considering two specific times: hospitalization and before surgery. In this analytical and cross-sectional study, the Hospital Anxiety and Depression Scale (HADS) was used to classify anxiety levels. Methodology: The time series of RR intervals were collected by Polar® monitor. Nonlinear methods and decision tree algorithm were combined with HADS scale to analyze the influence of the preoperative period on heart rate variability. The nonlinear methods used detrended fluctuation analysis (DFA), recurrence quantification analysis (RQA), and central tendency measure (CTM). Results: Among the 42 study participants, 13 $(31 \%)$ were classified as anxious at hospital admission. The applied time domain methods found an increase in the heart rate variability (HRV) values in all features analyzed ( $\mathrm{p}<0.05)$. CTM method showed HRV reduction for the values considering radius between 6 and 20 milliseconds $(p<0.05)$. Conclusion: The anxiety identified at admission is directly related to the reduction in heart rate variability demonstrated by nonlinear methods, such as the central tendency measure.
\end{abstract}

Keywords: Heart rate variability; Preoperative orthopedic surgery; Anxiety; Nonlinear analysis; Decision tree algorithm.

\section{Resumo}

A ansiedade é uma resposta emocional negativa a situações que ameaçam o sujeito. Objetivo: O presente estudo tem como objetivo verificar a influência da ansiedade na variabilidade da frequência cardíaca, considerando dois momentos específicos: a internação e antes da cirurgia. Neste estudo analítico e transversal, a Escala Hospitalar de Ansiedade e Depressão (HADS) foi utilizada para classificar os níveis de ansiedade. Metodologia: As séries temporais dos intervalos RR foram coletadas por monitor Polar®. Métodos não lineares e algoritmo de árvore de decisão foram combinados com a escala HADS para analisar a influência do período pré-operatório na variabilidade da frequência cardíaca. Os métodos não lineares usaram análise de flutuação sem tendência (DFA), análise de quantificação de recorrência (RQA) e medida de tendência central (CTM). Resultados: Entre os 42 participantes do estudo, 13 (31\%) foram classificados como ansiosos na admissão hospitalar. Os métodos aplicados no domínio do tempo encontraram aumento nos valores da variabilidade da frequência cardíaca (VFC) em todas as características analisadas ( $p<0,05)$. O 
método CTM mostrou redução da VFC para os valores considerando raios entre 6 e 20 milissegundos (p<0,05). Conclusão: A ansiedade identificada na admissão está diretamente relacionada à redução da variabilidade da frequência cardíaca demonstrada por métodos não lineares, como a medida de tendência central.

Palavras-chave: Variabilidade da frequência cardíaca; Pré-operatório de cirurgia ortopédica; Ansiedade; Análise não linear; Algoritmo de árvore de decisão.

\section{Resumen}

La ansiedad es una respuesta emocional negativa a situaciones que amenazan al sujeto. Objetivo: El presente estudio tiene como objetivo verificar la influencia de la ansiedad en la variabilidad de la frecuencia cardíaca, considerando dos momentos específicos: la hospitalización y antes de la cirugía. En este estudio analítico y transversal, se utilizó la Escala Hospitalaria de Ansiedad y Depresión (HADS) para clasificar los niveles de ansiedad. Método: Las series de tiempo de los intervalos RR fueron recopiladas por el monitor Polar®. Los métodos no lineales y el algoritmo de árbol de decisión se combinaron con la escala HADS para analizar la influencia del período preoperatorio en la variabilidad de la frecuencia cardíaca. Los métodos no lineales utilizaron análisis de fluctuación sin tendencia (DFA), análisis de cuantificación de recurrencia (RQA) y medida de tendencia central (CTM). Resultados: Entre los 42 participantes del estudio, $13(31 \%)$ fueron clasificados como ansiosos en el momento del ingreso al hospital. Los métodos aplicados en el dominio del tiempo encontraron un aumento en los valores de variabilidad de la frecuencia cardíaca (VFC) en todas las características analizadas ( $\mathrm{p}<0,05)$. El método CTM mostró reducción de la VFC para los valores considerando radios entre 6 y 20 milisegundos ( p <0.05). Conclusión: La ansiedad identificada al ingreso está directamente relacionada con la reducción de la variabilidad de la frecuencia cardíaca demostrada por métodos no lineales, como la medida de tendencia central.

Palabras clave: Variabilidad de la frecuencia cardíaca; Pacientes en cirurgía ortopédica preoperatoria; Ansiedad; Métodos no lineales; Algoritmo de árbol de decisión.

\section{Introduction}

The number of accidents and traumas in the Brazil continues to grow. This situation reflects directly on the organization and spending of the health system to attend these patients. Accidents and trauma can lead to complex bone fractures, with major blood loss (Datasus, 2019; Jorge et al., 2008; Melione \& De Mello-Jorge, 2008). Orthopedic trauma is one of the main existing morbidities in current society. It can compromise the function of individuals, their economic participation in society, and their family and social integration (Kfuri Junior, 2011). The hospital intervention indicated for the restoration of affected structures is often orthopedic surgery.

The preoperative period started with the diagnosis, then the decision for the surgery, and is followed by recovery and rehabilitation. This time can be accompanied by various feelings such as anxiety, insecurity, and fear of the unknown (Hayashi \& Garanhani, 2012). The preoperative anxiety may be related to a series of changes after surgery, including increased pain, nausea, vomiting, and postoperative anxiety (Caumo et al., 2001). One study with patients who underwent elective surgical procedures for small and medium issues showed that: $44.3 \%$ of patients had anxiety and $26.6 \%$ depression, with unemployed patients displaying a higher anxiety level (Marcolino et al., 2007).

Anxiety is a negative emotional response to situations that threaten the subject (Eysenck et al., 2007). State of anxiety (SA) can be defined as a state where the individual is unable to create a behavior to remove or change the event/object that is threatening an existing goal (Power \& Dalgleish, 2007). Many patients have high-stress levels, independent of the degree of complexity of the surgery, which can be related to the misinformation about the surgical procedures, anesthesia, and preoperative care (Christóforo \& Carvalho, 2009).

Disorders such as anxiety and depression can be measured by scales, inventories, and questionnaires, that can use clinical evaluation or self-evaluation. These instruments can facilitate communication among the healthcare team to decrease the pain and symptoms of anxiety and depression. The instrument for self-evaluation of anxiety and depression employed in this work is the Hospital Anxiety and Depression Scale (HADS), which is the most appropriate instrument for hospitalized patients. The HADS was used to assess the presence of anxiety and depression in patients preoperatively for elective surgeries (Marcolino et al., 2007). 
Anxiety disorders are among the most prevalent psychiatric disorders (Kessler et al., 2007). They can increase three to four times the risk of cardiovascular disease (CVD) (Härter et al., 2003; Kemp et al., 2015), and increase about twice the risk of cardiac mortality (Roest et al., 2010; Shibeshi et al., 2007). Thus, anxiety is associated with high blood pressure, heart rate (Noteboom et al., 2001), and (Homma \& Masaoka, 2008) respiratory rate. To evaluate the changes caused by anxiety, heart rate variability (HRV) is used. This non-invasive measurement is related to the balance of activities of the autonomic nervous system (ANS) considering the sympathetic and parasympathetic branches (Wijngaarden et al., 2013). This variability is normal and demonstrates the ability of the heart to respond to environmental and physiological stimuli (Kamath et al., 2016).

Chalmers et al. (2014) studied whether anxiety disorders or its symptoms are associated with heart rate variability. They concluded that the specific symptom of concern is associated with strong reductions of HRV (Chalmers et al., 2014). Reductions of HRV in the sleeping state reflect a cardiac autonomic dysfunction, which plays a key role in the development of cardiovascular diseases. These reductions can establish a link between anxiety and health problems (Chalmers et al., 2014; Malpas, 2010).

HRV is a quantitative marker related to the role of the ANS on the cardiac autonomic activity found in various pathologies of the cardiovascular system (Sakakibara, 2018). The HRV is regarded as a non-invasive tool to evaluate the ANS in various clinical situations (Task Force of the ESC-NASPE, 1996). The methods employed to analyze HRV include the time and frequency domain, and nonlinear methods (Aubert et al., 2003). The purpose of this study is to verify the influence of preoperative anxiety of orthopedic surgery on the HRV. We used the following methods from frequency domain (Tarvainen et al., 2014) and nonlinear methods: detrended fluctuation analysis (DFA) (Kemp et al., 2012), recurrence quantification analysis (RQA) (Javorka et al., 2008), and central tendency measure (CTM) (Dos Santos et al., 2015).

\section{Methodology}

\subsection{Local and Participants}

This analytical and transversal study employed quantitative approach. It was performed at the University Hospital of the Western of Paraná, located in Cascavel, state of Paraná, Brazil, during February and March 2016. The hospital attends approximately 2 million inhabitants with 195 hospital beds dedicated to the Brazilian Unified Public Health System (SUS). This study was approved by the Research Ethics Committee of from University of Vale do Paraiba under the number 1400688. All study participants agreed with participation in the research and they signed an Informed Consent Form in accordance with Helsinki Declaration.

The dataset was composed of 42 male participants between 18 up to 70 years old. The inclusion criteria were men waiting for orthopedic surgery of the upper limbs without presence of neurological impairments, obstructive pulmonary disease, respiratory distress, and symptoms of strong pain for all cases. The study participants declared that they did not use illicit drugs, antidepressant medications, beta-blockers, and anticonvulsants. They also did not have a pacemaker.

The reason for selecting the male gender is that men tend to show a potentially risky behavior that causes accidents (Albuquerque et al., 2012). This statement is justified by the increased frequency of the number of accidents involved male drivers (in cars or motorcycles) (De Castro et al., 2013).

\subsection{Experimental Protocol}

The data collected was divided into two steps: the first step was at the admission into the hospital and the second step was 2 hours before the orthopedic surgery. These procedures did not interfere in the conventional sector routine. In the first step, the study participant answered a sociodemographic questionnaire, and had their anthropometric measurements verified, vital signs taken, the level of anxiety and depression were classified using the HADS scale, and heart signals (RR interval time 
series) obtained. For the second step, the vital signs and heart signals were obtained from the study participants for 15 minutes.

The sociodemographic questionnaire comprises 10 questions with a maximum of four possible answers $(\mathrm{a} / \mathrm{b} / \mathrm{c} / \mathrm{d})$. The HADS instrument (Zigmond \& Snaith, 1983) consists of 14 questions - seven questions related to anxiety and seven related to depression status. Each possible response ranges from zero to three points, and the maximum score of the instrument is 21 for each section. According to HADS, a score higher or equal to 9 is considered a diagnosis of anxiety (Zigmond \& Snaith, 1983).

The RR interval time series were obtained by Polar® monitor (V800 or RS800) (Vanderlei et al., 2008) following the guidelines (Task Force of the ESC-NASPE, 1996). A strap on the bottom of the sternum bone was installed at the level of the patient's xiphoid. The study participant remained in the supine position for 15 minutes to record signals. All RR interval time series obtained were filtered using an adaptive filtering algorithm. This preprocessing reduces the influence of potential artifacts, ectopic beats, and other interference not arising from the sinus rhythm (Dos Santos et al., 2013). Adaptive filtering algorithm is based on the average and standard deviation of the RR interval time series obtained. It consists of three procedures: (a) removal of RR intervals less than $350 \mathrm{~ms}$ and higher than $1200 \mathrm{~ms}$, (b) adaptive procedure to estimate binomial filtered series, average, and standard deviation of the time series, and (c) adaptive procedure control for complementary exclusion rules to determine if the RR interval analyzed is from sinus rhythm.

\subsection{Heart Rate Variability Analysis}

\section{Frequency domain}

For the resting condition of the individuals, we used the frequency domain obtaining the power spectral density analysis (Brunetto et al., 2005; Cambri et al., 2008). Four frequency bands were delimited (Marães, 2010; Rajendra et al., 2006; Task Force of the ESC-NASPE, 1996): High frequency (HF), from 0.15 to $0.40 \mathrm{~Hz}$, is related to parasympathetic nervous system (PNS) (Marães, 2010; Rajendra et al., 2006). Low frequency (LF), from 0.04 to $0.15 \mathrm{~Hz}$, is modulated by the PNS and the sympathetic nervous system (SNS) and has been related to the regulatory system through pressure (baroregulatory), temperature (thermoregulatory), vasomotor activity, and the renin-angiotensin system. Very low frequency (VLF), from 0.01 to $0.04 \mathrm{~Hz}$, is related to renin-angiotensin system. For Ultra-low frequency (ULF), from 10-5 to 10-2 Hz, there is still no consensus on the relationship between this index and the ANS.

The LF/HF ratio reflects the absolute and relative changes between the sympathetic and parasympathetic components of the ANS, characterizing the sympathovagal balance of the heart (Rajendra et al., 2006; Melo et al., 2005). The autoregressive model (AR) was used to estimate the frequency spectrum. The model for the frequency spectrum estimation is a parametric method that provides high resolution frequency (Huikuri et al., 2003; Rajendra et al., 2006).

\section{Nonlinear methods}

The following nonlinear methods were used: Detrended Fluctuation Analysis (DFA) (Kemp et al., 2012), Recurrence Quantification Analysis (RQA) (Javorka et al., 2008), and Central Tendency Measure (CTM) (dos Santos et al., 2015). The DFA method quantifies the presence or absence of fractal correlation properties of the RR intervals. This is partly related to changes in the characteristic spectral behavior of the heart rate (Peng et al., 1995). This method is based on the analysis of the fractal correlation within the analyzed signal considering different time scales (Yeh et al., 2010). These correlations are divided into short-term fluctuations $(\alpha 1)$ and long-term $(\alpha 2)$. DFA exponents values close to 1.0 are characteristic of a fractal-like signal. It represents a balance between the total randomness and predictability. DFA exponent values close to 0.5 are associated with a random signal, while values close to 1.5 are a strongly correlated signal.

The DFA method was chosen for HRV analysis because it can stratify signals obtained from healthy subjects and cardiac patients (Yeh et al., 2010). Recent studies have reported the susceptibility of the DFA to the HRV analysis in the short- 
term (Zbilut \& Webber, 1992). The DFA was the basis of the study that analyzed a sequence of $\mathrm{R}$ waves of short-term measurements in non-medicated patients with depressive disorder. The authors identified a significant increase of DFA in this group compared to the control group (Kemp et al., 2012).

Recurrence Quantification Analysis (RQA) is suitable to analyze the HRV time series allowing direct quantification of the complex dynamics of heart rate modulation (Dos Santos et al., 2014; Javorka et al., 2008). This useful tool helps to elucidate changes in the ANS at the time (Marwan et al., 2007). The recurrence is a basic feature of the many dynamic systems, which is defined as the repeated occurrence of a certain state of the system at the time. Recurrence Plot (RP) is a graphical representation of such recurrences in a dynamic system (Webber \& Zbilut, 1994). The structures exposed by RP provide information about the properties of the system and can be quantified by RQA (Jeong et al., 2002; Marwan et al., 2002). RQA identified significant changes in the HRV of young patients with diabetes mellitus when compared with healthy individuals (Javorka et al., 2008).

Central Tendency Measure (CTM) quantifies the variability of the successive RR intervals in the time series (Cohen et al., 1996). This method provides a graphical representation (second-order difference plot) of the degree of variability of the RR interval time series and it displays the nonlinear aspects of the signal (Witten et al., 2011). CTM has been widely used in modeling of biological systems (Cohen et al., 1996), hemodynamic, and HRV analysis considering different groups of individuals (Dos Santos et al., 2015).

Through the CTM, a quantitative analysis of the time series variability was performed through a scatter plot. The CTM is calculated using a circular region of radius $\rho$, which must be chosen following the characteristics of the analyzed data. Around the origin, the points contained in the circle are counted and divided by the total points (Dos Santos et al., 2015).

\subsection{Decision Tree Classifier}

Decision Tree Classifier (J48) was used to verify the relationship between the HADS scale, data collected from sociodemographic questionnaire, vital signs, and features obtained from frequency domain and nonlinear methods. The J48 algorithm provides a hierarchical multistage classification from the dataset input. It divides a complex decision in many small parts until it reaches the final solution (Masetic \& Subasi, 2016).

The decision tree has different levels of the features classification, where the first one (root) represents the feature able to distinguish groups with greatest gain of information calculated. The combination between features in the different levels of the classifier leads to label classification. The software employed was WEKA (Safavian \& Landgrebe, 1991). The decision tree was used to identify and diagnose congestive heart failure patients (Maciel et al., 2015), and the risk of life in patients during screening activity in an emergency room ("Physical status: The use and interpretation of anthropometry," 1995).

\subsection{Statistical Analysis}

The data were submitted to descriptive statistical analysis. To compare variables obtained in the two steps of the data collected, we used the paired Student's t-test or Mann-Whitney test when the variables did not display Gaussian distribution. In all cases $\mathrm{p}<0.05$ was considered as significance level with a confidence interval of $95 \%$.

\section{Results}

\subsection{Characterization of the study participants}

In total, 42 men participated in this study, age $36.21 \pm 11.30$ years. Table 1 displays the sociodemographic characteristic of the study participants. According to sociodemographic characteristics, 22 (52.38\%) men were married, and the participates earned an average of US\$ 500 (equivalent to R $\$ 2,800$ ) (see Table 1). 
Table 1. Socio demographic characterization of 42 patients collected preoperatively to orthopedic surgery.

\begin{tabular}{lcc}
\hline Variables & $\mathbf{n}(\boldsymbol{\%})$ & Average $\mathbf{\pm}$ SD \\
\hline Age (years) & - & $36.21 \pm 11.30$ \\
Married & $22(52.38)$ & - \\
Single & $14(33.33)$ & - \\
Divorced & $6(14.29)$ & - \\
Religion & & - \\
Catholic & $28(66.67)$ & - \\
Protestant & $8(19.05)$ & - \\
Other religion & $2(4.76)$ & - \\
No religion & $4(9.52)$ & $1.35 \pm 1.26$ \\
Number of children & - & $2.61 \pm 1.69$ \\
Income (minimum wage) & - & \\
\hline
\end{tabular}

$\mathrm{SD}=$ standard deviation

Source: Authors.

Table 2 displays the anthropometric characteristics obtained from the study participants. The average weight was $77.44 \pm 15.82 \mathrm{~kg}$, the height of participants was $1.73 \pm 0.08 \mathrm{~m}$. The average body mass index (BMI) was $25.85 \mathrm{Kg} / \mathrm{m} 2$, indicating the participants were overweight (60). Most of men did not smoke (61.8\%), and they did not use medicines (90.48 $\%$ ). In terms of physical activities, $33.33 \%$ of the study participants did physical exercises on average 2.78 days per week.

Table 2. Anthropometrics of the study participants.

\begin{tabular}{lcc}
\hline Features & n (\%) & Average \pm SD \\
\hline Weight $(\mathbf{K g})$ & - & $77.44 \pm 15.82$ \\
Height $(\mathbf{m})$ & - & $1.73 \pm 0.08$ \\
BMI $\left(\mathbf{k g} / \mathbf{m}^{2}\right)$ & - & $25.85 \pm 5.02$ \\
Smoking & $16(38.10)$ & - \\
Yes & $26(61.90)$ & - \\
No & & - \\
Use of medicines & $4(9.52)$ & - \\
Yes & $38(90.48)$ & - \\
No & & - \\
Practice physical activity & $14(33.33)$ & \\
Yes & $28(66.67)$ & - \\
No & - & \\
Frequency of the physical activity (days) & & \\
\hline
\end{tabular}

$\mathrm{SD}=$ standard deviation

Source: Authors. 
Table 3 presents the comparison of the vital signs from the study participants obtained in the two steps: hospital admission and 2 hours before the surgery. The heart rate (HR) was slightly lower at the second step than in the first step. There was a statistically significant difference $(\mathrm{p}<0.05)$ between HR in both steps.

Table 3. Comparison of the vital signs from study participants at hospital admission (admission) and 2 hours before the surgery (preoperative). The paired student's t-test or Mann-Whitney test (no Gaussian data) were used.

\begin{tabular}{lccc}
\hline Features & $\begin{array}{c}\text { Admission } \\
\text { Average } \pm \text { SD }\end{array}$ & $\begin{array}{c}\text { Preoperative } \\
\text { Average } \pm \text { SD }\end{array}$ & p-value \\
\hline SBP $(\mathrm{mmHg})$ & $122.61 \pm 14.49$ & $121.66 \pm 15.28$ & 0.770 \\
DBP $(\mathrm{mmHg})$ & $74.52 \pm 11.51$ & $74.28 \pm 11.29$ & 0.881 \\
& $90.55 \pm 11.59$ & $90.08 \pm 11.46$ & 0.827 \\
MAP (mmHg) & $75.57 \pm 14.60$ & $69.59 \pm 11.16$ & $0.038^{*}$ \\
HR (bpm) & $17.19 \pm 3.35$ & $17.5 \pm 3.11$ & 0.662 \\
RR (rpm) & $36.28 \pm 0.58$ & $36.27 \pm 0.45$ & 0.917 \\
Temperature $\left({ }^{\circ} \mathrm{C}\right)$ & & & \\
\hline
\end{tabular}

SD = standard deviation; Preoperative $=2$ hours before the surgery; SBP: systolic blood pressure; DBP: diastolic blood pressure; MAP: mean arterial pressure; HR: heart rate; RR: respiratory rate. $*$ t-test $=\mathrm{p}<0.05$. Source: Authors.

\subsection{Heart rate variability analysis}

According to the HADS scale obtained from individuals, two groups were established: HADS $\geq 9$ (classified as anxious group) and HADS $<9$ (non-anxious group). Table 4 displays the values of the applied methods (frequency domain, DFA and RQA methods) on the RR interval time series obtained from the study participants in the first step (admission hospital). According to HADS scale for this step (HADS-A), 13 (31\%) of the study participants were classified as anxious, and $29(69 \%)$ were classified as non-anxious. There was no statistically significant difference between the groups (HADS-A $\geq$ 9 and HADS-A < 9) considering the RR interval time series obtained from first step. 
Table 4. Comparison of indexes of the frequency domain, DFA, and RQA methods obtained from RR interval time series between HADS-A $\geq 9$ and HADS-A $<9$ groups.

\begin{tabular}{|c|c|c|c|}
\hline Methods applied & $\begin{array}{c}\text { HADS-A } \geq 9 \\
\text { Average } \pm \text { SD } \\
\quad \mathbf{n}=\mathbf{1 3}\end{array}$ & $\begin{array}{c}\text { HADS-A }<9 \\
\text { Average } \pm \text { SD } \\
\mathbf{n}=\mathbf{2 9}\end{array}$ & p-value \\
\hline \multicolumn{4}{|l|}{ Frequency domain } \\
\hline VLF peak (Hz) & $0.004 \pm 0.004$ & $0.005 \pm 0.006$ & 0.662 \\
\hline LF peak $(\mathrm{Hz})$ & $0.08 \pm 0.03$ & $0.07 \pm 0.02$ & $0.049 *$ \\
\hline HF peak $(\mathrm{Hz})$ & $0.19 \pm 0.04$ & $0.19 \pm 0.05$ & 0.784 \\
\hline VLF power $\left(\mathrm{ms}^{2}\right)$ & $0.0015 \pm 0.0013$ & $0.001 \pm 0.001$ & 0.889 \\
\hline VLF power $(\%)$ & $47.30 \pm 15.58$ & $53.93 \pm 13.22$ & 0.197 \\
\hline $\mathrm{LF}$ power $\left(\mathrm{ms}^{2}\right)$ & $0.0010 \pm 0.0007$ & $0.0008 \pm 0.0007$ & 0.453 \\
\hline LF power $(\%)$ & $34.91 \pm 12.50$ & $31.66 \pm 9.69$ & 0.416 \\
\hline LF power (n.u.) & $67.81 \pm 17.39$ & $70.31 \pm 15.15$ & 0.659 \\
\hline HF power $\left(\mathrm{ms}^{2}\right)$ & $0.0006 \pm 0.0006$ & $0.0004 \pm 0.0005$ & 0.367 \\
\hline HF power $(\%)$ & $17.75 \pm 13.07$ & $14.38 \pm 10.57$ & 0.423 \\
\hline HF power (n.u.) & $32.11 \pm 17.33$ & $29.63 \pm 15.14$ & 0.660 \\
\hline $\mathrm{LF} / \mathrm{HF}$ power $\left(\mathrm{ms}^{2}\right)$ & $3.06 \pm 2.14$ & $3.74 \pm 3.46$ & 0.445 \\
\hline Total power $\left(\mathrm{ms}^{2}\right)$ & $0.003 \pm 0.002$ & $0.0027 \pm 0.002$ & 0.525 \\
\hline \multicolumn{4}{|l|}{ Nonlinear - DFA } \\
\hline Short-term $(\alpha 1)$ & $1.22 \pm 0.24$ & $1.26 \pm 0.26$ & 0.634 \\
\hline Long-term $(\alpha 2)$ & $0.90 \pm 0.15$ & $0.92 \pm 0.13$ & 0.740 \\
\hline \multicolumn{4}{|l|}{ Nonlinear - RQA } \\
\hline L max (beats) & $519.00 \pm 340.26$ & $657.10 \pm 318.81$ & 0.277 \\
\hline $\operatorname{REC}(\%)$ & $0.35 \pm 0.07$ & $0.39 \pm 0.06$ & 0.121 \\
\hline $\operatorname{DET}(\%)$ & $0.98 \pm 0.01$ & $0.99 \pm 0.005$ & 0.327 \\
\hline ShanEn & $3.32 \pm 0.31$ & $3.42 \pm 0.23$ & 0.165 \\
\hline
\end{tabular}

$\mathrm{SD}=$ standard deviation; $* \mathrm{p}<0.05-$ Mann-Whitney test Source: Authors.

Table 5 presents the CTM values for different radius obtained for RR interval time series from two steps: hospital admission and preoperative. The CTM values reduced in the second step for all different radius used. There was a statistically significant difference for $\mathrm{r}=6 \mathrm{~ms}$ up to $\mathrm{r}=20 \mathrm{~ms}$. 
Table 5. Comparison of CTM values (average \pm SD) for different radius (ms) between two steps: hospital admission (A) and preoperative $(\mathrm{P})$.

\begin{tabular}{|c|c|c|c|c|c|c|c|}
\hline $\begin{array}{l}\text { Radius } \\
(\mathrm{ms})\end{array}$ & $\begin{array}{l}\text { Admission } \\
\text { Average } \pm \text { SD }\end{array}$ & $\begin{array}{l}\text { Preoperative } \\
\text { Average } \pm \text { SD }\end{array}$ & p-value & $\begin{array}{l}\text { Radius } \\
\text { (ms) }\end{array}$ & $\begin{array}{l}\text { Admission } \\
\text { Average } \pm \text { SD }\end{array}$ & $\begin{array}{c}\text { Preoperative } \\
\text { Average } \pm \text { SD }\end{array}$ & p-value \\
\hline \multirow[t]{2}{*}{ CTM1 } & $0.0008 \pm$ & $0.0005 \pm$ & 0.418 & CTM15 & $0.2686 \pm$ & $0.1572 \pm$ & $0.013^{*}$ \\
\hline & 0.0015 & 0.0009 & & & 0.2387 & 0.1505 & \\
\hline \multirow[t]{2}{*}{ СТM2 } & $0.0062 \pm$ & $0.0035 \pm$ & 0.145 & CTM16 & $0.2907 \pm$ & $0.1746 \pm$ & $0.013^{*}$ \\
\hline & 0.0088 & 0.0081 & & & 0.2504 & 0.1587 & \\
\hline \multirow[t]{2}{*}{ CTM3 } & $0.0163 \pm$ & $0.0087 \pm$ & 0.092 & CTM17 & $0.3110 \pm$ & $0.1902 \pm$ & $0.013^{*}$ \\
\hline & 0.0231 & 0.0171 & & & 0.2605 & 0.1657 & \\
\hline \multirow[t]{2}{*}{ CTM4 } & $0.0285 \pm$ & $0.0147 \pm$ & 0.062 & CTM18 & $0.3329 \pm$ & $0.2083 \pm$ & $0.014^{*}$ \\
\hline & 0.0382 & 0.0277 & & & 0.2705 & 0.1742 & \\
\hline \multirow[t]{2}{*}{ CTM5 } & $0.0432 \pm$ & $0.0224 \pm$ & 0.054 & CTM19 & $0.3542 \pm$ & $0.2260 \pm$ & $0.015^{*}$ \\
\hline & 0.0562 & 0.0399 & & & 0.2801 & 0.1826 & \\
\hline \multirow[t]{2}{*}{ CTM6 } & $0.0656 \pm$ & $0.0340 \pm$ & $0.044 *$ & СТM20 & $0.3732 \pm$ & $0.2438 \pm$ & $0.017^{*}$ \\
\hline & 0.0827 & 0.0565 & & & 0.2874 & 0.1904 & \\
\hline \multirow[t]{2}{*}{ CTM7 } & $0.0839 \pm$ & $0.0435 \pm$ & $0.033^{*}$ & СТM30 & $0.5313 \pm$ & $0.4125 \pm$ & 0.061 \\
\hline & 0.1007 & 0.0664 & & & 0.3168 & 0.2537 & \\
\hline \multirow[t]{2}{*}{ СТМ8 } & $0.1064 \pm$ & $0.0555 \pm$ & $0.027 *$ & CTM40 & $0.6439 \pm$ & $0.5512 \pm$ & 0.139 \\
\hline & 0.1223 & 0.0808 & & & 0.2999 & 0.2685 & \\
\hline \multirow[t]{2}{*}{ СТМ9 } & $0.1308 \pm$ & $0.0694 \pm$ & $0.022 *$ & CTM50 & $0.7208 \pm$ & $0.6562 \pm$ & 0.266 \\
\hline & 0.1429 & 0.0941 & & & 0.2724 & 0.2566 & \\
\hline \multirow[t]{2}{*}{ CTM10 } & $0.1531 \pm$ & $0.0814 \pm$ & $0.018^{*}$ & СТM60 & $0.7816 \pm$ & $0.7341 \pm$ & 0.359 \\
\hline & 0.1604 & 0.1045 & & & 0.2387 & 0.2330 & \\
\hline \multirow[t]{2}{*}{ CTM11 } & $0.1776 \pm$ & $0.0953 \pm$ & $0.014 *$ & СТM70 & $0.8293 \pm$ & $0.7937 \pm$ & 0.432 \\
\hline & 0.1788 & 0.1143 & & & 0.2035 & 0.2093 & \\
\hline \multirow[t]{2}{*}{ CTM12 } & $0.1979 \pm$ & $0.1086 \pm$ & $0.014^{*}$ & СТM80 & $0.8651 \pm$ & $0.8381 \pm$ & 0.497 \\
\hline & 0.1942 & 0.1236 & & & 0.1767 & 0.1863 & \\
\hline \multirow[t]{2}{*}{ CTM13 } & $0.2217 \pm$ & $0.1250 \pm$ & $0.014 *$ & СТМ90 & $0.8944 \pm$ & $0.8709 \pm$ & 0.497 \\
\hline & 0.2092 & 0.1344 & & & 0.1486 & 0.1665 & \\
\hline \multirow[t]{2}{*}{ CTM14 } & $0.2470 \pm$ & $0.1422 \pm$ & $0.013^{*}$ & CTM100 & $0.9169 \pm$ & $0.8960 \pm$ & 0.487 \\
\hline & 0.2244 & 0.1431 & & & 0.1250 & 0.1487 & \\
\hline
\end{tabular}

$\mathrm{SD}=$ standard deviation; $*$ student $\mathrm{t}$-test $=\mathrm{p}<0.05$ Source: Authors.

The J48 algorithm was used to correlate the different data from the sociodemographic questionnaire, vital signs, and features from nonlinear methods applied on the RR interval time series (only the admission step) with the HADS scale. This algorithm provides a decision tree as an output to understand the correlation between quantitative and qualitative features. In 
this study, the label classifications were anxious (HADS-A $\geq 9$ ) and non-anxious (HADS-A < 9).

In total, 63 features were used as input for J48 algorithm: 14 features from sociodemographic questionnaire and vital signs, 13 features from frequency domain, and 36 features from nonlinear methods (DFA, RQA, and CTM). Figure 1 shows the decision tree obtained for the input set. Notice that the algorithm considered 6 important features in the 5 different levels for classification of the whole dataset. The root level of the decision tree was the DFA- $\alpha 2$. This represents the feature with greatest gain of information able to distinguish the groups. In terms of accuracy of the classification, 40 instances (participants) were correctly classified representing $95.2 \%$, and 2 instances were incorrectly classified representing $4.8 \%$. The kappa index was 0.89 and the average of the absolute error was 0.07 .

Figure 1. Decision tree obtained by J48 algorithm.

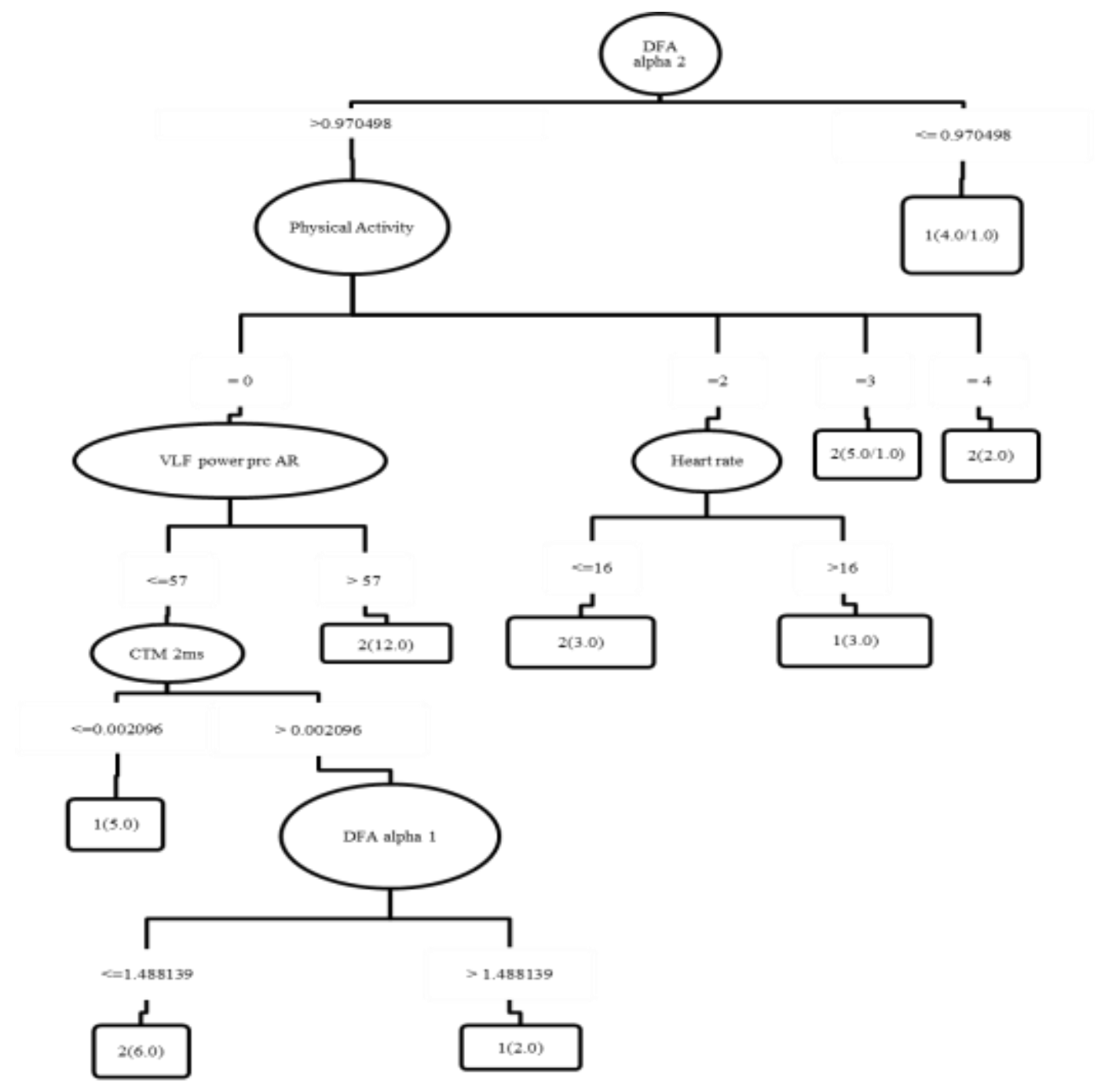

Source: Authors.

\section{Discussion}

The sociodemographic data revealed the average age of the study participants was 36 years old, which is similarly to those found in other studies (Lima et al., 2004; Pereira et al., 2014). However, the literature pointed to a high incidence of orthopedic procedures in the elderly population (Albuquerque et al., 2012). Concerning the gender, some studies reported high incidence (60.7 \% up to $89.6 \%$ ) of the orthopedic trauma in men (Albuquerque et al., 2013; Sakaki et al., 2014; Vargas et al., 
2006).

Vital signs showed reduction for all variables in the second measurement (preoperative) with a statistically significant difference for heart rate (HR). This reduction may be related to the patients' adaptation into the hospital environment after admission. For the patient's stay in the hospital, their doubts about the surgery procedure must be clarified. This can prevent patients from having negative feelings or anxiety resulting from misinformation about the procedures. It suggests that knowledge developed by patients can change their health behavior (Lake et al., 2002).

The analysis of HRV linear indices at admission period showed that the imbalance between the sympathetic and parasympathetic branches persists in the period preceding the surgery, with a predominance of sympathetic, which would justify the higher values of $\alpha 1$ at the admission compared to the preoperative period. Additionally, no significant differences were observed for the features of RQA. A study carried out in Portugal is noteworthy in stating that the application of nonlinear methods, in the domain of time or frequency alone is unable to characterize HRV through dynamic parameters. This is because the non-stationary character of humans makes the study of HRV limited by traditional methods.

The decision tree generated by J48 algorithm presents the DFA- $\alpha 2$ (Figure 1) as the feature with highest gain of information. Considering this dataset, DFA- $\alpha 2$ was considered by the classifier an important attribute to determine if the HRV could be related to the level of anxiety of the study participants in hospital admission. The average value of the DFA- $\alpha 1$ for the anxious group was 1.22 (values related to fractal-like signal), while the average value for non-anxious group was 1.26 (tending to a nonlinear dynamic system). The average values of the DFA- $\alpha 2$ showed a small variation between anxious (0.90) and nonanxious (0.92) groups, where both values were related to features from fractal-like signals. Melillo et al. (2011) identified an association between pre-competitive anxiety and the increase in the level of the exponent DFA- $\alpha 1$ in a short period of time (Melillo et al., 2011). However, Millar et al. (2009) identified reduction of DFA- $\alpha 1$ values under stressful situations in academics (Millar et al., 2009).

In this study, the behavior of DFA- $\alpha 1$ indicated alterations in the HR dynamics. The difference is expected for the function of the sympathetic and parasympathetic components under the HR, i.e., when one component increases the activity over HR, the other one decreases its activity. There was a strong short-term fractal correlation according to the increase of the DFA- $\alpha 1$ value (Tulppo et al., 2001, 2005; Vanderlei et al., 2010; Wessel et al., 2001). The analysis of the linear indices of $\mathrm{HRV}$ at the hospital admission found that the imbalance between the sympathetic and parasympathetic components of the ANS persists in the period before the surgery. Thus, the SNS predominates, which would justify the increase of the DFA- $\alpha 1$ values at the hospital admission compared to the preoperative step.

We observed a lower heart rate variability in patients classified as anxious than in non-anxious patients, although without statistical difference. These data corroborate the results of other studies, which revealed that anxiety disorders are associated with significant reductions in HRV (Associação Brasileira para o Estudo da Obesidade e da Síndrome Metabólica [ABESO], 2016; Chalmers et al., 2014; Javorka et al., 2008). Anxiety, as well as other conditions that alter the state of health of the individual, interfered directly in HRV.

Analysis of the results of HRV by CTM at two different collection times (admission and preoperative) identified a reduction of the values in all the spectra, however, with a statistically significant difference between 6 and 20 milliseconds rays (Table 5). The values of the spectrum at the patient's admission are bigger, which is far from zero, denoting a lower HRV at this time compared to the preoperative period.

The HRV in the time series is quantified by measuring the number of different points scattered in a representation of the second order. The high variability is represented by a high degree of dispersion, while the low variability implies a high concentration of points near the origin (Dos Santos et al., 2015). In this study, this fact can be explained by several factors, such as fear, not being familiar with the environment, and lack of information. At the second data collection, the patient had 
already received the information according to the routine of the institution, was receiving the medication prescribed by the doctor, and the problem that caused the hospitalization was to be resolved.

Another variable pointed to by the $\mathrm{J} 48$ tool for having a relationship with the object of study was physical activity. Among the 42 participants, 28 (66.67\%) responded that they do not perform activities, demonstrating the existence of a sedentary condition, which is one of the main factors that raise the risk for the occurrence of cardiovascular diseases (CVD) (Billman, 2009). Moderate physical exercise can increase vagal control in the heart and reduce sympathetic activity (Montano et al., 2009). Thus, exercise can restore sympathetic balance, inducing increased parasympathetic vagal modulation and decreasing sympathetic modulation in the heart, thus favoring the prognosis of the individual cardiovascular disease carrier. However, the mechanisms for this are not yet clear and the most accepted hypothesis is that exercise can increase the constant relationship between cardiovascular and respiratory centers in the CNS and respiratory center exerts an inhibitory effect on sympathetic activity (Montano et al., 2009).

From the analyzes performed with J48 algorithm, we concluded that the anxiety identified at the time of admission was directly related to the reduction of HRV for some methods, even without statistically significant difference. Reductions in HRV in the sleep state reflect an autonomic cardiac dysfunction, and this plays a key role in the development of cardiovascular diseases.

\section{Conclusion}

When hospital patients do not receive adequate perioperative assistance, they can have a distorted perception of reality, since the hospital environment and, especially, the surgical center is completely unknown and perceived as hostile to most people.

Therefore, it is necessary to know the relationship between the anxiety of patients in the periods leading up to the surgery and the heart rate variability, taking into account the importance that the changes of this variability may pose to the health of the individual and the risks that this provides to the other perioperative steps. From this knowledge, the institution may develop a permanent education program to improve the quality of care offered by the client, as well as conduct new research on the topic.

\section{Acknowledgments}

L. dos Santos thanks the São Paulo Research Foundation - Fapesp (Grant no 2018/03517-8) and CNPq (Grant no 450133/2019-2) for their financial support.

\section{References}

Associação Brasileira para o Estudo da Obesidade e da Síndrome Metabólica. (2016). Diretrizes Brasileiras de Obesidade. https://abeso.org.br/wpcontent/uploads/2019/12/Diretrizes-Download-Diretrizes-Brasileiras-de-Obesidade-2016.pdf

Albuquerque, A. L. M. de., Sousa Filho, P. G. T. de., Braga Junior, M. B., Cavalcante Neto, J. de S., Medeiros, B. B. L. de., \& Lopes, M. B. G. (2012). Epidemiologia das fraturas em pacientes do interior do Ceará tratadas pelo SUS. Acta Ortopédica Brasileira, 20(2), 66-69. https://doi.org/10.1590/S141378522012000200001

Albuquerque, R. P., Hara, R., Prado, J., Schiavo, L., Giordano, V., \& Amaral, N. P. do. (2013). Estudo epidemiológico das fraturas do planalto tibial em hospital de trauma nível I. Acta Ortopédica Brasileira. https://doi.org/10.1590/s1413-78522013000200008

Aubert, A. E., Seps, B., \& Beckers, F. (2003). Heart Rate Variability in Athletes. In Sports Medicine. https://doi.org/10.2165/00007256-200333120-00003

Billman, G. E. (2009). Cardiac autonomic neural remodeling and susceptibility to sudden cardiac death: effect of endurance exercise training. American Journal of Physiology-Heart and Circulatory Physiology, 297(4), H1171-H1193. https://doi.org/10.1152/ajpheart.00534.2009

Brunetto, A. F., Silva, B. M., Roseguini, B. T., Hirai, D. M., \& Guedes, D. P. (2005). Limiar ventilatório e variabilidade da freqüência cardíaca em adolescentes. Revista Brasileira de Medicina Do Esporte, 11(1), 22-27. https://doi.org/10.1590/S1517-86922005000100003 
Cambri, L. T., Fronchetti, L., De-Oliveira, F. R., Gevaerd, M. S., \& Oliveira, F. R. (2008). Variabilidade da frequência cardíaca e controlo metabólico. Arq Sanny Pesq Saúde. https://doi.org/10.1017/CBO9781107415324.004

Caumo, W., Schmidt, A. P., Schneider, C. N., Bergmann, J., Iwamoto, C. W., Adamatti, L. C., Bandeira, D., \& Ferreira, M. B. C. (2001). Risk factors for postoperative anxiety in adults. Anaesthesia. https://doi.org/10.1046/j.1365-2044.2001.01842.x

Chalmers, J. A., Quintana, D. S., Abbott, M. J. A., \& Kemp, A. H. (2014). Anxiety disorders are associated with reduced heart rate variability: A metaanalysis. Frontiers in Psychiatry. https://doi.org/10.3389/fpsyt.2014.00080

Christóforo, B. E. B., \& Carvalho, D. S. (2009). Cuidados de enfermagem realizados ao paciente cirúrgico no período pré-operatório. Revista Da Escola de Enfermagem Da USP, 43(1), 14-22. https://doi.org/10.1590/S0080-62342009000100002

Cohen, M. E., Hudson, D. L., \& Deedwania, P. Ć. (1996). Applying continuous chaotic modeling to cardiac signal analysis. In IEEE Engineering in Medicine and Biology Magazine. https://doi.org/10.1109/51.537065

DATASUS. (2019). DataSUS/TABNET. Ministério Da Saúde. Available in http://www2.datasus.gov.br/DATASUS.

De Castro, R. R. M., Ribeiro, N. F., De Andrade, A. M., \& Jaques, B. D. (2013). Orthopedics nursing patients' profile of a public hospital in Salvador-Bahia. Acta Ortopedica Brasileira. https://doi.org/10.1590/S1413-78522013000400001

Dos Santos, L., Barroso, J. J., De Godoy, M. F., Macau, E. E. N., \& Freitas, U. S. (2014). Recurrence quantification analysis as a tool for discrimination among different dynamics classes: The heart rate variability associated to different age groups. Springer Proceedings in Mathematics and Statistics, 103. https://doi.org/10.1007/978-3-319-09531-8_8

Dos Santos, L., Barroso, J. J., Macau, E. E. N., \& de Godoy, M. F. (2015). Assessment of heart rate variability by application of central tendency measure. Medical and Biological Engineering and Computing, 53(11). https://doi.org/10.1007/s11517-015-1390-8

Dos Santos, L., Barroso, J. J., Macau, E. E. N., \& de Godoy, M. F. (2013). Application of an automatic adaptive filter for Heart Rate Variability analysis. Medical Engineering \& Physics. https://doi.org/10.1016/j.medengphy.2013.07.009

Eysenck, M. W., Derakshan, N., Santos, R., \& Calvo, M. G. (2007). Anxiety and cognitive performance: Attentional control theory. In Emotion. https://doi.org/10.1037/1528-3542.7.2.336

Härter, M. C., Conway, K. P., \& Merikangas, K. R. (2003). Associations between anxiety disorders and physical illness. European Archives of Psychiatry and Clinical Neuroscience. https://doi.org/10.1007/s00406-003-0449-y

Hayashi, J. M., \& Garanhani, M. L. (2012). Perioperatory care of the orthopaedic patient from the nursing team perspective. Revista Mineira de Enfermagem.

Homma, I., \& Masaoka, Y. (2008). Breathing rhythms and emotions. In Experimental Physiology. https://doi.org/10.1113/expphysiol.2008.042424

Huikuri, H. V., Mäkikallio, T. H., \& Perkiömäki, J. (2003). Measurement of Heart Rate Variability by Methods Based on Nonlinear Dynamics. Journal of Electrocardiology. https://doi.org/10.1016/j.jelectrocard.2003.09.021

Javorka, M., Trunkvalterova, Z., Tonhajzerova, I., Lazarova, Z., Javorkova, J., \& Javorka, K. (2008). Recurrences in heart rate dynamics are changed in patients with diabetes mellitus. Clinical Physiology and Functional Imaging, 28(5), 326-331. https://doi.org/10.1111/j.1475-097X.2008.00813.x

Jeong, J., Gore, J. C., \& Peterson, B. S. (2002). A method for determinism in short time series, and its application to stationary EEG. IEEE Transactions on Biomedical Engineering. https://doi.org/10.1109/TBME.2002.804581

Jorge, M. H. P. de M., Laurenti, R., Lima-Costa, M. F., Gotlieb, S. L. D., \& Filho, A. D. P. C. (2008). A mortalidade de idosos no Brasil: a questão das causas mal definidas. Epidemiologia e Serviços de Saúde, 17(4). https://doi.org/10.5123/S1679-49742008000400004

Kamath, M. V., Watanabe, M. A., \& Upton, A. R. M. (2016). Heart rate variability (HRV) signal analysis: Clinical applications. In Heart Rate Variability (HRV) Signal Analysis: Clinical Applications.

Kemp, A. H., Brunoni, A. R., Nunes, M. A., Santos, I. S., Goulart, A. C., Ribeiro, A. L., Bensenor, I. M., \& Lotufo, P. A. (2015). The association between mood and anxiety disorders, and coronary heart disease in Brazil: a cross-sectional analysis on the Brazilian longitudinal study of adult health (ELSA-Brasil). Frontiers in Psychology, 6. https://doi.org/10.3389/fpsyg.2015.00187

Kemp, A. H., Quintana, D. S., Felmingham, K. L., Matthews, S., \& Jelinek, H. F. (2012). Depression, comorbid anxiety disorders, and heart rate variability in physically healthy, unmedicated patients: Implications for cardiovascular risk. PLoS ONE. https://doi.org/10.1371/journal.pone.0030777

Kessler, R. C., Angermeyer, M., Anthony, J. C., DE Graaf, R., Demyttenaere, K., Gasquet, I., DE Girolamo, G., Gluzman, S., Gureje, O., Haro, J. M., Kawakami, N., Karam, A., Levinson, D., Medina Mora, M. E., Oakley Browne, M. A., Posada-Villa, J., Stein, D. J., Adley Tsang, C. H., Aguilar-Gaxiola, S., \& Ustün, T. B. (2007). Lifetime prevalence and age-of-onset distributions of mental disorders in the World Health Organization's World Mental Health Survey Initiative. World Psychiatry: Official Journal of the World Psychiatric Association (WPA).

Kfuri Junior, M. (2011). O trauma ortopédico no Brasil. Revista Brasileira de Ortopedia, 46, 0-0. https://doi.org/10.1590/S0102-36162011000700003

Lake, D. E., Richman, J. S., Griffin, M. P., \& Moorman, J. R. (2002). Sample entropy analysis of neonatal heart rate variability. American Journal of Physiology-Regulatory, Integrative and Comparative Physiology, 283(3), R789-R797. https://doi.org/10.1152/ajpregu.00069.2002

Lima, A. L. L. M., Zumiotti, A. V., Uip, D. E., \& Silva, J. dos S. (2004). Fatores preditivos de infecção em pacientes com fraturas expostas nos membros inferiores. Acta Ortopédica Brasileira. https://doi.org/10.1590/s1413-78522004000100005 
Maciel, T. V., Seus, V. D. R., Machado, K. D. S., \& Borges, E. N. (2015). Mineração de dados em triagem de risco de saúde. Revista Brasileira de Computação Aplicada. https://doi.org/10.5335/rbca.2015.4651

Malpas, S. C. (2010). Sympathetic Nervous System Overactivity and Its Role in the Development of Cardiovascular Disease. Physiological Reviews, 90(2), 513-557. https://doi.org/10.1152/physrev.00007.2009

Marães, V. R. F. S. (2010). Heart rate and its variability: Analysis and applications. Heart Rate and Its Variability: Analysis and Applications.

Marcolino, J. A. M., Mathias, L. A. da S. T., Piccinini Filho, L., Guaratini, A. A., Suzuki, F. M., \& Alli, L. A. C. (2007). Hospital Anxiety and Depression Scale: a study on the validation of the criteria and reliability on preoperative patients. Revista Brasileira de Anestesiologia. https://doi.org/10.1590/S003470942007000100006

Marwan, N., Carmen Romano, M., Thiel, M., \& Kurths, J. (2007). Recurrence plots for the analysis of complex systems. In Physics Reports. https://doi.org/10.1016/j.physrep.2006.11.001

Marwan, N., Wessel, N., Meyerfeldt, U., Schirdewan, A., \& Kurths, J. (2002). Recurrence-plot-based measures of complexity and their application to heartrate-variability data. Physical Review E - Statistical, Nonlinear, and Soft Matter Physics. https://doi.org/10.1103/PhysRevE.66.026702

Masetic, Z., \& Subasi, A. (2016). Congestive heart failure detection using random forest classifier. Computer Methods and Programs in Biomedicine, 130, 5464. https://doi.org/10.1016/j.cmpb.2016.03.020

Melillo, P., Bracale, M., \& Pecchia, L. (2011). Nonlinear Heart Rate Variability features for real-life stress detection. Case study: Students under stress due to university examination. BioMedical Engineering Online. https://doi.org/10.1186/1475-925X-10-96

Melione, L. P. R., \& De Mello-Jorge, M. H. P. (2008). Unified national health system costs in São José dos Campos, São Paulo State, Brazil, for hospital admissions due to external causes. Cadernos de Saude Publica. https://doi.org/10.1590/s0102-311x2008000800010

Melo, R. C., Santos, M. D. B., Silva, E., Quitério, R. J., Moreno, M. A., Reis, M. S., Verzola, I. A., Oliveira, L., Martins, L. E. B., Gallo-Junior, L., \& Catai, A. M. (2005). Effects of age and physical activity on the autonomic control of heart rate in healthy men. Brazilian Journal of Medical and Biological Research, 38(9), 1331-1338. https://doi.org/10.1590/S0100-879X2005000900007

Millar, P. J., Rakobowchuk, M., Adams, M. M., Hicks, A. L., McCartney, N., \& MacDonald, M. J. (2009). Effects of short-term training on heart rate dynamics in individuals with spinal cord injury. Autonomic Neuroscience, 150(1-2), 116-121. https://doi.org/10.1016/j.autneu.2009.03.012

Montano, N., Porta, A., Cogliati, C., Costantino, G., Tobaldini, E., Casali, K. R., \& Iellamo, F. (2009). Heart rate variability explored in the frequency domain: A tool to investigate the link between heart and behavior. Neuroscience \& Biobehavioral Reviews, 33(2), 71-80. https://doi.org/10.1016/j.neubiorev.2008.07.006

Noteboom, J. T., Barnholt, K. R., \& Enoka, R. M. (2001). Activation of the arousal response and impairment of performance increase with anxiety and stressor intensity. Journal of Applied Physiology. https://doi.org/10.1152/jappl.2001.91.5.2093

Peng, C. -K., Havlin, S., Stanley, H. E., \& Goldberger, A. L. (1995). Quantification of scaling exponents and crossover phenomena in nonstationary heartbeat time series. Chaos: An Interdisciplinary Journal of Nonlinear Science, 5(1), 82-87. https://doi.org/10.1063/1.166141

Pereira, B. R. R., Mendoza, I. Y. Q., Couto, B. R. G. M., Ercole, F. F., \& Goveia, V. R. (2014). Artroplastia do quadril: prevenção de infecção do sítio cirúrgico. Revista Sobecc, 19(4), 181-187. https://doi.org/10.5327/Z1414-4425201400040002

Physical status: The use and interpretation of anthropometry. (1995). In World Health Organization - Technical Report Series. https://doi.org/10.1093/ajcn/64.5.830

Power, M., \& Dalgleish, T. (2007). Cognition and Emotion. In Cognition and Emotion: From Order to Disorder: Second Edition. Psychology Press. https://doi.org/10.4324/9780203934487

Rajendra, A. U., Paul Joseph, K., Kannathal, N., Lim, C. M., \& Suri, J. S. (2006). Heart rate variability: a review. Medical \& Biological Engineering \& Computing, 44(12), 1031-1051. https://doi.org/10.1007/s11517-006-0119-0

Roest, A. M., Martens, E. J., de Jonge, P., \& Denollet, J. (2010). Anxiety and Risk of Incident Coronary Heart Disease. A Meta-Analysis. Journal of the American College of Cardiology. https://doi.org/10.1016/j.jacc.2010.03.034

Safavian, S. R., \& Landgrebe, D. (1991). A survey of decision tree classifier methodology. IEEE Transactions on Systems, Man, and Cybernetics, 21(3), 660674. https://doi.org/10.1109/21.97458

Sakaki, M. H., Matsumura, B. A. R., Dotta, T. D. A. G., Pontin, P. A., Santos, A. L. G. dos, \& Fernandes, T. D. (2014). Epidemiologic study of ankle fractures in a tertiary hospital. Acta Ortopédica Brasileira, 22(2), 90-93. https://doi.org/10.1590/1413-78522014220200874

Sakakibara, M. (2018). Clinical application of heart rate variability. The Proceedings of the Annual Convention of the Japanese Psychological Association. https://doi.org/10.4992/pacjpa.82.0_tws-011

Shibeshi, W. A., Young-Xu, Y., \& Blatt, C. M. (2007). Anxiety Worsens Prognosis in Patients With Coronary Artery Disease. Journal of the American College of Cardiology. https://doi.org/10.1016/j.jacc.2007.03.007

Tarvainen, M. P., Niskanen, J. P., Lipponen, J. A., Ranta-aho, P. O., \& Karjalainen, P. A. (2014). Kubios HRV - Heart rate variability analysis software. Computer Methods and Programs in Biomedicine. https://doi.org/10.1016/j.cmpb.2013.07.024

Task Force of the ESC-NASPE. (1996). Heart Rate Variability: Standards of Measurement, Physiological Interpretation, and Clinical Use. Circulation. https://doi.org/10.1161/01.CIR.93.5.1043 
Research, Society and Development, v. 10, n. 8, e14410817237, 2021

(CC BY 4.0) | ISSN 2525-3409 | DOI: http://dx.doi.org/10.33448/rsd-v10i8.17237

Tulppo, M. P., Hughson, R. L., Mäkikallio, T. H., Airaksinen, K. E. J., Seppänen, T., \& Huikuri, H. V. (2001). Effects of exercise and passive head-up tilt on fractal and complexity properties of heart rate dynamics. American Journal of Physiology-Heart and Circulatory Physiology, 280(3), H1081-H1087. https://doi.org/10.1152/ajpheart.2001.280.3.H1081

Tulppo, M. P., Kiviniemi, A. M., Hautala, A. J., Kallio, M., Seppänen, T., Mäkikallio, T. H., \& Heikki, H. V. (2005). Physiological background of the loss of fractal heart rate dynamics. Circulation. https://doi.org/10.1161/CIRCULATIONAHA.104.523712

Vanderlei, L. C. M., Pastre, C. M., Júnior, I. F. F., \& de Godoy, M. F. (2010). Fractal correlation of heart rate variability in obese children. Autonomic Neuroscience, 155(1-2), 125-129. https://doi.org/10.1016/j.autneu.2010.02.002

Vanderlei, L. C. M., Silva, R. A., Pastre, C. M., Azevedo, F. M., \& Godoy, M. F. (2008). Comparison of the Polar S810i monitor and the ECG for the analysis of heart rate variability in the time and frequency domains. Brazilian Journal of Medical and Biological Research, 41(10), 854-859. https://doi.org/10.1590/S0100-879X2008005000039

Vargas, T. V. P., Maia, E. M., \& Dantas, R. A. S. (2006). Patient feelings during the preoperative period for cardiac surgery. Revista Latino-Americana de Enfermagem, 14(3), 383-388. https://doi.org/10.1590/S0104-11692006000300012

Webber, C. L., \& Zbilut, J. P. (1994). Dynamical assessment of physiological systems and states using recurrence plot strategies. Journal of Applied Physiology, 76(2), 965-973. https://doi.org/10.1152/jappl.1994.76.2.965

Wessel, N., Marwan, N., Meyerfeldt, U., Schirdewan, A., \& Kurths, J. (2001). Recurrence quantification analysis to characterise the heart rate variability before the onset of ventricular tachycardia. Lecture Notes in Computer Science (Including Subseries Lecture Notes in Artificial Intelligence and Lecture Notes in Bioinformatics). https://doi.org/10.1007/3-540-45497-7_45

Wijngaarden, M. A., Pijl, H., van Dijk, K. W., Klaassen, E. S., \& Burggraaf, J. (2013). Obesity is associated with an altered autonomic nervous system response to nutrient restriction. Clinical Endocrinology, n/a-n/a. https://doi.org/10.1111/cen.12100

Witten, I. H., Frank, E., Hall, M. A., \& Pal, C. J. (2011). Data Mining: Practical Machine Learning Tools and Techniques. In Data Mining: Practical Machine Learning Tools and Techniques. Elsevier. https://doi.org/10.1016/C2009-0-19715-5

Yeh, R. G., Chen, G. Y., Shieh, J. S., \& Kuo, C. D. (2010). Parameter investigation of detrended fluctuation analysis for short-term human heart rate variability. Journal of Medical and Biological Engineering. https://doi.org/10.5405/jmbe.30.5.02

Zbilut, J. P., \& Webber, C. L. (1992). Embeddings and delays as derived from quantification of recurrence plots. Physics Letters A, 171(3-4), 199-203. https://doi.org/10.1016/0375-9601(92)90426-M

Zigmond, A. S., \& Snaith, R. P. (1983). The Hospital Anxiety and Depression Scale. Acta Psychiatrica Scandinavica. https://doi.org/10.1111/j.16000447.1983.tb09716.x 